\title{
SPECIMENS OF THE BILLFISH XIPHIORHYNCHUS VAN BENEDEN, 1871, FROM THE YAZOO CLAY FORMATION (LATE EOCENE), LOUISIANA
}

\author{
HARRY L. FIERSTINE, ${ }^{*}, 1$ and GARY L. STRINGER ${ }^{2},{ }^{1}$ Biological Sciences Department, California Polytechnic State \\ University, San Luis Obispo, California 93407-0401 U.S.A., hfiersti@calpoly.edu; ${ }^{2}$ Department of Geosciences, University of \\ Louisiana at Monroe, Monroe, Louisiana 71209-5220 U.S.A., stringer@ulm.edu
}

In 1974, Fierstine and Applegate described a new species of billfish, Xiphiorhynchus kimblalocki, based on a rostrum, two vertebrae, and two partial fin spines, from the Yazoo Clay Formation, late Eocene, Mississippi, U.S.A. This was the first substantiated record of Xiphiorhynchus van Beneden, 1871, outside of western Europe. Since this initial discovery, there have been three other records of Xiphiorhynchus in the United States. Based on four rostral fragments, Breard and Stringer (1995) listed Xiphiorhynchus among the numerous marine vertebrates they collected in the Yazoo Clay Formation, late Eocene, Louisiana. There was no formal description and identification was restricted to the generic level. Fierstine and Starnes (2005) identified $X$. cf. $X$. eocaenicus (Woodward, 1901), in the Moodys Branch Formation, middle Eocene, Mississippi, based on comparison with $X$. eocaenicus (Woodward, 1901), from the Bracklesham Beds, middle Eocene, England. Monsch and colleagues (2005) confirmed that the holotype of $X$. rotundus (Woodward, 1901), a featureless, phosphate impregnated rostrum with a vague provenance, was collected in the late Oligocene or early Miocene of the Charleston region, South Carolina.

Here we report new specimens (three partial rostra) of $X i$ phiorhynchus that were collected in the Yazoo Clay Formation, late Eocene, Louisiana, U.S.A. Two of the better preserved specimens are identified as $X$. kimblalocki, and although the third specimen is poorly preserved and only identified to genus, it belongs to a species distinct from $X$. kimblalocki. We compare all three specimens to other species of Xiphiorhynchus and discuss the difficulty in confirming the identity of rostra that have been referred to $X$. priscus (Agassiz, 1844) because the holotype of $X$. priscus is a poorly preserved skull without a rostrum.

\section{LOCALITY DATA AND STRATIGRAPHY}

The rostral material for this study was collected in the upland prairies located in Caldwell Parish, Louisiana, between the old community of Copenhagen and the Ouachita River, about 9.7 $\mathrm{km}$ southeast of Columbia and east of State Highway 849 (Columbia $1 / 24,000$ quadrangle, $x=591.900 \mathrm{~m}, \mathrm{y}=3544.100 \mathrm{~m}$ ). The prairies and exposures along the Ouachita River have been scientifically studied since 1831 , and were the sites for the initial discovery of the Eocene whale Basilosauns cetoides (Gibbes, 1847). A location map is found in Breard and Stringer (1995:fig. 2 ), and a measured section is shown in Nolf and Stringer (2003:fig. 1). The age of the Yazoo Clay Formation in Louisiana is considered to be Priabonian, with the possible exception of the

\footnotetext{
"Corresponding author.
}

lowermost and uppermost strata (Manning and Standhardt, 1986). Radiometric dates for the Yazoo Clay Formation are approximately $34 \mathrm{Ma}$ (Dockery, 1996). In some areas of Louisiana, the Yazoo Clay Formation is divided into members, which are, respectively from the base to top, the Tullos, Union Church, and Verda. The Yazoo Clay sediments at the site belong to the Tullos Member (Fig. 1). Since there are over $50 \mathrm{~m}$ of the Tullos Member exposed at the site, the locality is divided into two parts (Locality 1a and Locality 1b). Locality $1 \mathrm{a}$ is in the lower part of the section near the contact with the underlying Moodys Branch Formation, and Locality $1 \mathrm{~b}$ is approximatcly $35 \mathrm{~m}$ higher stratigraphically than Locality 1a. Specimen NLU1F-1 was collected at Locality $1 \mathrm{a}$ and specimens NLU1F-2 and NLU1F-3 were collected at Locality $1 \mathrm{~b}$.

\section{MATERIALS AND METHODS}

\section{Comparative Materials}

The comparative materials are identical to those listed in Fierstine and Starnes (2005) and for the sake of brevity are not repeated here.

Institutional Abbreviations-BMNH, The Natural History Museum, London, England; IRSNB, Institut royal des Sciences naturelles de Belgique, Brussels, Belgium; LACM, Natural History Museum of Los Angeles County, Los Angeles, California; MNHN, Múseum national d'Histoire naturelle, Paris, France; NLU, The University of Louisiana at Monroe Museum of Natural History, Monroe, Louisiana; SMNS, Staatliches Museum für Naturkunde, Stuttgart, Germany.

Anatomical Abbreviations-alv, alveolus (i); $\alpha$, angle of taper of rostrum; cc, central canal; D, depth of rostrum; fstr, fine striations; gr, groove; L, length of rostrum; led, dorsolateral nutrient canal; lcv, ventrolateral nutrient canal; $\mathbf{W}$, width of rostrum; x.s., cross section.

\section{Methods}

Wc follow the methodology of Fierstine and Starnes (2005) for identifying specimens of Xiphiorhynchus using rostral characters. Measurements were taken directly from the specimen where possible, otherwise they were taken from computed tomography (CT) images. We follow the Eocene time scale of Berggren and colleagues (1995). In the past we placed billfishes in the Suborder Scombroidei (Fierstine, 2001; Fierstine and Starnes, 2005; Monsch et al., 2005), but now there is compelling evidence that billfishes belong in the Suborder Xiphioidei. T. Orrell, B. Collette, and G. D. Johnson have a manuscript in review (submitted to Bulletin of Marine Science, January, 2006) 


\begin{tabular}{|c|c|c|c|c|c|}
\hline AGE & STAGE & GROUP & $\begin{array}{l}\text { FORM- } \\
\text { ATION }\end{array}$ & $\begin{array}{c}\text { MEMBER/ } \\
\text { BED }\end{array}$ & LITHOLOGY \\
\hline \multirow{5}{*}{$\begin{array}{l}\text { L } \\
\text { A } \\
\text { T } \\
\text { E } \\
\text { E } \\
\text { O } \\
\text { C } \\
\text { E } \\
\text { N } \\
\text { E }\end{array}$} & \multirow{4}{*}{$\begin{array}{l}\text { P } \\
\text { R } \\
\text { I } \\
\text { A } \\
\text { B } \\
\text { O } \\
\text { N } \\
\text { I } \\
\text { A } \\
\text { N }\end{array}$} & \multirow{5}{*}{$\begin{array}{l}\mathbf{J} \\
\mathbf{A} \\
\mathbf{C} \\
\mathbf{K} \\
\mathbf{S} \\
\mathrm{O} \\
\mathbf{N}\end{array}$} & \multirow{5}{*}{$\begin{array}{l}\mathrm{Y} \\
\mathrm{A} \\
\mathrm{Z} \\
\mathrm{O} \\
\mathrm{O} \\
\mathrm{C} \\
\mathrm{L} \\
\mathrm{A} \\
\mathrm{Y}\end{array}$} & $\begin{array}{l}\text { DANVILLE } \\
\text { LANDING } \\
\text { BEDS }\end{array}$ & \begin{tabular}{|c|} 
Interbedded sands, \\
clays, with fossiliferous \\
concretions \\
(32 m thick)
\end{tabular} \\
\hline & & & & $\begin{array}{c}\text { VERDA } \\
\text { MEMBER }\end{array}$ & \begin{tabular}{|l|} 
Lignitic clays, silty \\
sands, lenticular marine \\
sandstone, and clays \\
(64 to $72 \mathrm{~m}$ thick)
\end{tabular} \\
\hline & & & & $\begin{array}{c}\text { UNION CHURCH } \\
\text { MEMBER }\end{array}$ & \begin{tabular}{|l|} 
Sandy silts, calcareous \\
concretions $(4.8 \mathrm{~m}$ thick
\end{tabular} \\
\hline & & & & $\begin{array}{l}\text { TULLOS } \\
\text { MEMBER }\end{array}$ & $\begin{array}{l}\text { Deep blue-gray clay } \\
\text { (weathers tan), minor } \\
\text { marl and limy clay } \\
\text { beds, abundant fossils } \\
\text { (24 to } 56 \mathrm{~m} \text { thick) }\end{array}$ \\
\hline & BARTINL & & & & \\
\hline
\end{tabular}

FIGURE 1. Stratigraphic column of the Jackson Group (upper Eocene), Ouachita River section, Louisiana.

that demonstrates support for separate scombroid and xiphioid clades based on phylogenetic analysis of the single copy nuclear locus Tmo-4C4 (T. Orrell, pers. comm., April 28, 2006).

\section{SYSTEMATIC PALEONTOLOGY}

Class ACTINOPTERYGII (sensu Nelson, 1994)

Division TELEOSTEI Müller, 1844

Order PERCIFORMES Bleeker, 1859

Suborder XIPHIOIDEI Swainson, 1839

Family XIPHIIDAE Swainson, 1839

Subfamily XIPHIORHYNCHINAE Regan, 1909

Genus XIPHIORHYNCHUS van Beneden, 1871

Type Species-Xiphiorhynchus elegans van Beneden, 1871 (IRSNB P642, late Eocene, Belgium).

Diagnosis-In cross section, the rostrum contains two types of longitudinal canals, an unpaired central canal and two pairs of lateral nutrient canals, and both types vary as to how far they extend distally. The dorsal pair of lateral nutrient canals is positioned closer to the mid-line than the ventral pair of lateral nutrient canals.

TABLE 1. Various measurements (in mm), except $\alpha$ (in degrees), of two distal rostra with tip missing (specimens NLU1F-1, NLU1F-2) of Xiphiorhynchus kimblalocki Fierstine and Applegate, 1974, and a middle segment of a rostrum (specimen NLU1F-3) of Xiphiorhynchus sp., all from the Yazoo Clay Formation, upper Eocene, Louisiana.

\begin{tabular}{lccr}
\hline & \multicolumn{3}{c}{ Measurements } \\
\cline { 2 - 4 } Character & NLU1F-1 & NLU1F-2 & NLU1F-3 \\
\hline L & 140.3 & 152.5 & 108.0 \\
D proximal & 26.5 & 26.2 & 17.0 \\
W proximal & 33.2 & 34.5 & est. 37.0 \\
D distal & 19.4 & 21.7 & 15.0 \\
W distal & 20.1 & 24.0 & 28.0 \\
D* & 24.0 & 24.0 & - \\
W* & 28.6 & 29.4 & - \\
$\alpha$ & 7.5 & 6.5 & 7.0
\end{tabular}

Proximal (posterior) measurements were taken at the posterior end of each rostrum where both the depth (D) and width (W) were complete. Similarly, the distal (anterior) measurements were taken at the anterior end of each rostrum where both $\mathrm{D}$ and $\mathrm{W}$ were complete. Abbreviations: defined in Materials and Methods section of text. Characters with an asterisk $(*)$ were measured from CT scans taken at $71 \mathrm{~mm}$ from the distal end (NLU1F-1) and $75.5 \mathrm{~mm}$ from the distal end (NLU1F-2). Measurement preceded by 'est.' is an estimate.

\section{XIPHIORHYNCHUS KIMBLALOCKI Fierstine and Applegate, 1974 \\ (Fig. 2, Tables 1, 2)}

Type Species-LACM 25575.1-6, a rostrum, partial anterior abdominal vertebra, partial posterior caudal vertebra, vertebral fragment, and two partial fin spines from LACM locality 7003, Shubuta Member, Yazoo Clay Formation, upper Eocene, Scott County, Mississippi.

Referred Specimens-Two distal rostra, both missing their tips (specimens NLU1F-1 and NLU1F-2).

Locality and Age-Localities $1 \mathrm{a}$ and $1 \mathrm{~b}$ (ca. $35 \mathrm{~m}$ higher in the section than 1a), Copenhagen, Caldwell Parish, Louisiana; Yazoo Clay Formation, upper Eocene.

Description and Comparison with Other XiphiorhynchinsSpecimen NLU1F-1 is $140.3 \mathrm{~mm}$ long and has a D/W (depth/ width) ratio that varies from 0.80 proximally (posteriorly) to 0.97 distally (anteriorly). The angle of taper $(\alpha)$ is $7.5^{\circ}$. Its entire outer surface is worn and has a woody (fibrous) texture (Figs. 2A-C). Dorsally there are three to four faint, discontinuous, longitudinal grooves that do not seem to represent fusion of bony elements and may have been caused by postmortem forces. A shallow groove extends along the entire ventral mid-line and probably represents the line of fusion of the right and left premaxillae. No teeth and very few alveoli have been preserved. There is a tiny patch of alveoli on the postero-dorsal surface and a few scattered along the ventral mid-line groove. The alveoli are
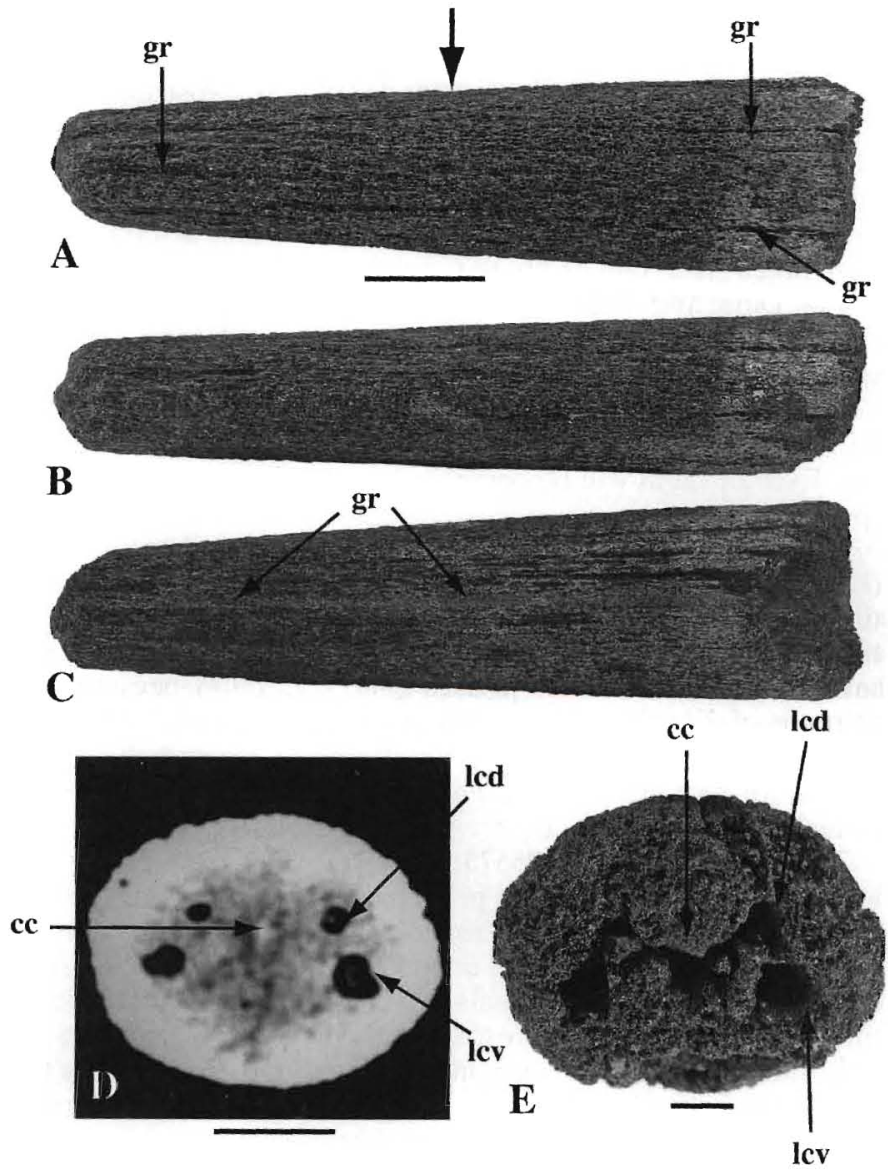

FIGURE 2. Rostrum of Xiphiorhynchus kimblalocki Fierstine and Applegate, 1974, specimen NLU1F-1, upper Eocene, Yazoo Clay Formation, Louisiana, U.S.A. A, dorsal view; B, lateral view; C, ventral view; D, cross section (computer tomography image) of the rostrum taken $71 \mathrm{~mm}$ from distal tip as indicated by pointer in $\mathrm{A}$; $\mathbf{E}$, view of proximal (posterior) broken end of specimen. Abbreviations listed in text. Scale bar equals $20 \mathrm{~mm}(\mathrm{~A}-\mathrm{C}), 10 \mathrm{~mm}$ (D) and $5 \mathrm{~mm}$ (E). 
TABLE 2. Variables of the rostra of two specimens (NLU1F-1, NLU1F-2) of Xiphiorhwnchus kimblalocki Fierstine and Applegate, 1974, and a poorly preserved rostrum (NIU1F-3) of Xiphiorhynchus sp. compared to the same variables, if known, in six holotype species of Xiphiorhynchus and five specimens identified by Casier (1966) as $X$. priscus.

\begin{tabular}{|c|c|c|c|c|c|}
\hline Variable & NLU1F-1 & NLU1F-2 & NLU1F-3 & $\begin{array}{l}X \text { kimblalocki Fierstine } \\
\text { and Applegate } 1974, \\
\text { holotype LACM } \\
2575.1\end{array}$ & $\begin{array}{l}X . \text { aegyptiacus Weiler, } \\
1929, \text { holotype, SMNS } \\
13134\end{array}$ \\
\hline $\mathrm{D} / \mathrm{W}$ & 0.84 & 0.82 & 0.45 & 0.81 & 0.45 \\
\hline$\alpha\left({ }^{c}\right)$ & 7.5 & 6.5 & 7.0 & 10.0 & 11.5 \\
\hline $\begin{array}{l}\text { Shape of x.s. of fused } \\
\text { portion }\end{array}$ & Oval & Oval & $\begin{array}{l}\text { Dorsal round, ventral } \\
\text { flat }\end{array}$ & Oval & $\begin{array}{l}\text { Dorsal round, ventral } \\
\text { flat }\end{array}$ \\
\hline Fine striations & No & No & Yes & $\begin{array}{l}\text { No (coarse striations } \\
\text { visible posteriorly) }\end{array}$ & $\begin{array}{l}\text { Yes, with fibrous texture } \\
\text { distally }\end{array}$ \\
\hline Central canal present & Yes & Yes & $?$ & Yes & No \\
\hline $\begin{array}{l}\text { Fornuation or locality/ } \\
\text { age }\end{array}$ & Yazoo Clay & Fm, Louisiana, U.S.A.late & Eocene & $\begin{array}{l}\text { Yazoo Clay Fm, } \\
\text { Mississippi, U.S.A.' } \\
\text { late Eocene }\end{array}$ & $\begin{array}{l}\text { Egypt/middle or late } \\
\text { Eocene }\end{array}$ \\
\hline
\end{tabular}

A range of values with their average (in parentbeses) is given for $X$. priscus. For specimens NLU1F-1 and NLU1F-2: D/W was measured 71.0 and $75.5 \mathrm{~mm}$ from the distal (anterior) tip, respectively. For $X$. aegyptiacus, $X$. parvus, and three specimens of $X$. priscus (BMNH P23838, $36133,36133 \mathrm{a}$ ): D/W was measured at the proximal (posterior) end of the rostrum. For specimen BMNH P9716 of $X$. priscus: D/W was measured at the distal end of the rostrum. For $X$. elegaris, $X$. eocaenicus, $X$. kimblalocki, and specimen BMNH P10003 of $X$. priscus: D/W was measured $120 \mathrm{~mm}, 150 \mathrm{~mm}, 170$ $\mathrm{mm}$, and $109 \mathrm{~mm}$ from the distal end of the rostrum, respectively. For $X$. rotundus: $\mathrm{D} / \mathrm{W}$ was measured $97 \mathrm{~mm}$ from the proximal end of the rostrum. See text for definition of abbreviations.

approximately $0.2 \mathrm{~mm}$ in diameter. A CT scan taken $71 \mathrm{~mm}$ from the distal end (Fig. 2D) illustrates the canal system. The paired lateral canals (lcd, lcv) are very distinct, whereas the central canal (cc) is opaque and hard to distinguish from the surrounding bone. Both the central and lateral canals are visible as cavitics at the broken posterior (proximal) end of the specimen (Fig. 2E).

Specimen NLU1F-2 is $152.5 \mathrm{~mm}$ long and has a $D / W$ ratio that varies from 0.76 proximally to 0.90 distally. The rostrum is very similar in morphology and state of preservation to NLU1F-1. The angle of taper is $6.5^{\circ}$. It has the same surface texture, one faint groove on its dorsal surface rather than several, a groove along the ventral mid-line, no teeth and very few alveoli. A CT scan taken $75.5 \mathrm{~mm}$ from the distal end contains an opaque central canal and distinct set of lateral canals. The central canal and lateral canals are visible at the broken posterior end of the specimen.

Comparing variables in Table 2, specimens NLU1F-1 and NLU1F-2 are similar to $X$. kimblalocki, $X$, parvus, and $X$. priscus. Fach of them will be compared separately to the Louisiana specimens.

Xiphiorhynchus parvus is only known by the holotype (BMNH P21306, London Clay, England, early Eocene), a distal tip of a rostrum that is $21 \mathrm{~mm}$ long. Because its proximal ends bear two canals rather than the usual four that are typically found in xiphiorhynchins, Monsch (2005) placed the specimen in "Istiophorini Incertae sedis sp. non Xiphiorhynchus." Although we don't necessarily agree with his allocation, we do believe that until more is known about $X$. parvus, it is not prudent to refer the Louisiana specimens to it.

The rostrum (LACM 25575.1) of X. kimblalocki is $580 \mathrm{~mm}$ long and $83.5 \mathrm{~mm}$ wide at its proximal (posterior) end (Fierstine and Applcgate, 1974). At $170 \mathrm{smm}$ from the distal tip, the rostrum is $40.6 \mathrm{~mm}$ wide and $32.9 \mathrm{~mm}$ deep with a $\mathrm{D} / \mathrm{W}$ ratio of 0.81 . The cross section at $170 \mathrm{~mm}$ reveals a led and $\mathrm{lcy}$ on the left side and three canals on the right. Most likely the two dorsal canals on the right side represent a division in the led and the third canal is the lcv. Based on variation of the number and position of nutrient canals in the rostrum of extant istiophorids (Fierstine and Voigt, 1996; Fierstine. 2001), we believe the three longitudinal canals on the right side of the rostrum represent normal variation in a xiphiorhynchin. Dorsal and lateral surfaces of the distal one-half have a fibrous texture, whereas the proximal one-fourth bas longitudinal striations that are coarse. The intervening region is relatively smooth. The ventral surface of the rostrum is covered with alveoli that range from $0.25 \mathrm{~mm}$ to $0.4 \mathrm{~mm}$ in diameter.
The holotype of $X$. priscus is a skull without a rostrum (MNHN PIE 474, London Clay, England, early Eocene), thus there is no way of knowing whether Casicr (1966) identified the rostra correctly. In contrast to our skepticism, Monsch (2005: 462) concluded that skulls similar to the holotype and rostra were associated and correctly identified as $X$. priscus. The five referred specimens from the London Clay vary in length from $118 \mathrm{~mm}$ to $197 \mathrm{~mm}$. Three (BMNH P10003, 23838, 36133) come from the anterior region of the rostrum, one (BMNH 36133a) from the middle region, and one (BMNH P9716) from the posterior region. The texture of the dorsal surface is usually fibrous, however the proximal end of specimen BMNH P9716 bears coarse longitudinal striations. On most specimens, alveoli are found on both the dorsal and ventral surfaces and their diameters range from $0.25 \mathrm{~mm}$ to $0.5 \mathrm{~mm}$. The central canal is visible in three specimens (BMNH P23838, 36133, 36133a), usually at the proximal end only. In a cross-section from the distal end, specimen BMNH 36133 a has three lateral canals on the left side, not unlike the canals on the right side of $X$. kimblalocki. Because there is a wide range of variation in the angle of taper among the five specimens, it is possible that more than one species is represented. Some of the specimens identified as $X$. priscus and the holotype of $X$. kimblalocki share numerous features (surface texture, angle of taper, $D / W$ ratio, size of denticles) that suggest to us that they could be conspecific. If some of the rostra from London Clay are shown to belong to $X$. priscus, then based on priority, $X$. kimblalocki must be synonymized with $X$. priscus. Intil this problem is settled, $X$. kimblalocki remains a valid species and is the best choice for the identification of the Louisiana specimens, not only because they share similar morphologies, but because also they were collected in the same chronostratigraphic unit.

\section{XIPHIORHYNCHUS SP.}

(Fig. 3; Tables 1, 2)

Material-Specimen NLU1F-3, a poorly preserved middle segment of a rostrum.

Locality and Age-Same as specimen NLU1F-2.

Description and Comparison with Other XiphiorhynchinsSpecimen NLU1F-3 is a segment from the region of the rostrum where the paired premaxillae fuse into a single, distal structure (Fig. 3). The specimen was collected in several pieces that were cemented together to approximate the original shape. Except for the extreme distal end, the internal (medullary) bone was not 
TABLE 2. (Extended)

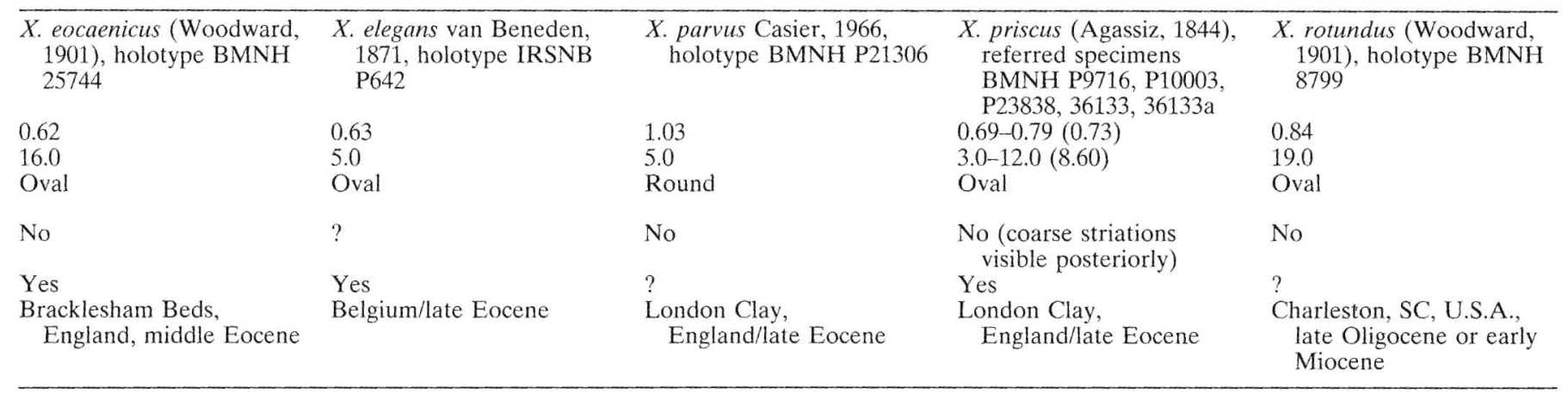

preserved. The rostrum is $108 \mathrm{~mm}$ long and its $\mathrm{D} / \mathrm{W}$ ratio varies from 0.45 proximally to 0.54 distally. Its cross-sectional shape is round dorsally and flat ventrally. The angle of taper is $7^{\circ}$. Most of the dorsal surface is covered with very fine longitudinal ridges (Fig. 3A). Anteriorly, the dorsal surface has a woody texture in some places, but we think the layer that contained the ridges was worn away to expose the fibrous texture. Dorsally, two fractures, one along the midline and the other on the right side lateral to the mid-line, represent fusions in the premaxillae. The midline fracture conforms to the fusion of the right and left premaxillae, and the right fracture represents the division between the dorsal and ventral rami of the right premaxillae. A shallow groove on the left, posterolateral part of the rostrum illustrates the division of the left premaxillary rami in the original, undamaged state. The ventral surface has a midline fracture that represents the fusion of the premaxillae. Large patches of alveoli (each alveolus is approximately $0.2 \mathrm{~mm}$ in diameter) are visible on the ventral (Fig. 3E) and ventrolateral surfaces and a few scattered alveoli are visible on the dorsal surface of the rostrum. The paired lateral canals (lcd, lcv) are visible on the anterior (distal) end of the specimen (Fig. 3D). The central canal is not visible, but this probably is the result of the lack of preservation of medullary bone.

Comparing variables in Table 2, specimen NLU1F-3 is most similar to the holotype and only known specimen of $X$. aegyptiacus Weiler, 1929 (SMNS 13134, Kasr (Qasr) el Sagha, Egypt, middle or late Eocene), in three features:D/W ratio, dorsal surface primarily covered with fine striations, and a cross section with a round dorsal surface and flat ventral surface. Unfortunately, matrix covers much most of its ventral and part of the dorsal surface. Both specimens are segments from the middle of a rostrum, however, the Egyptian specimen may be from a segment slightly more distal than specimen NLU1F-3, because the texture of its dorsal surface changes near its distal end from having striations to fibrous. This transition was observed in two specimens that display both textures ( $X$. kimblalocki, holotype; $X$. aegyptiacus, holotype).

Only three nutrient canals are visible in cross-section at the distal end, a right lcd and lcv, and a left Icd. No denticles or alveoli are visible, however, the matrix may be concealing them.

Although specimen NLU1F-3 is similar to $X$. aegyptiacus in a few features, it differs in its angle of taper and possibly in the presence of a fibrous texture on its distal dorsal surface. Until better preserved specimens can be studied and the matrix is removed from the Egyptian specimen, we make the conservative decision and identify specimen NLU1F-3 to genus only.

\section{PALEOENVIRONMENTAL INTERPRETATIONS}

A study of 5,559 fish otoliths from the same locality (Nolf and Stringer, 2003), indicated a teleost fauna of 43 taxa, which is the most diversified assemblage presently known from a single $\mathrm{Pa}$ leogene locality in the Gulf Coast region of the U.S.A. The study of the fish otoliths provided excellent paleoenvironmental data for the occurrence of the billfish fossils as did earlier studies on foraminfers (Breard and Stringer, 1995), ostracodes (Kilmarten, 1982; Breard and Stringer, 1995), and barnacles (Zullo and Perreault, 1986). A distinctive difference in the paleoenvironments of Locality $1 \mathrm{a}$ and Locality $1 \mathrm{~b}$ was ascertained indicating that the billfish were found in at least two distinct marine environments,
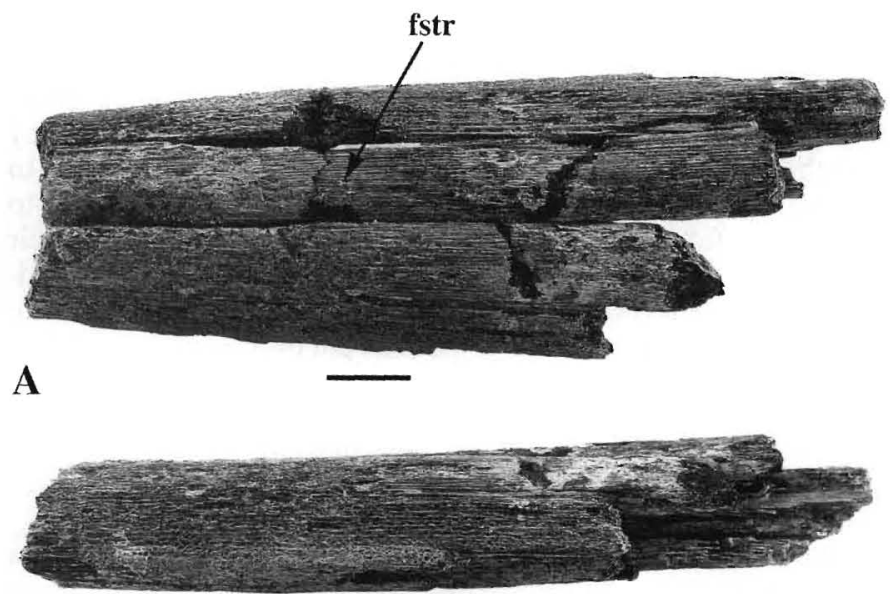

$\mathbf{B}$

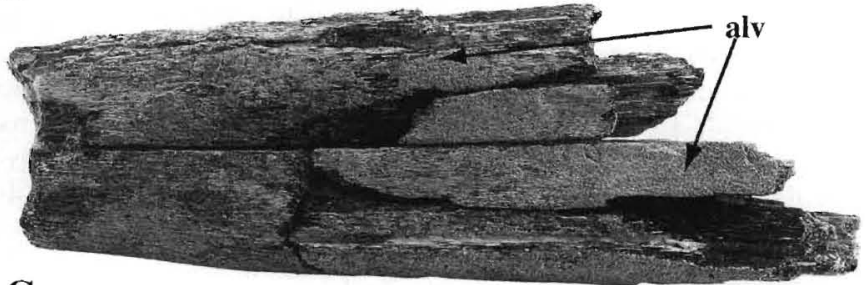

C

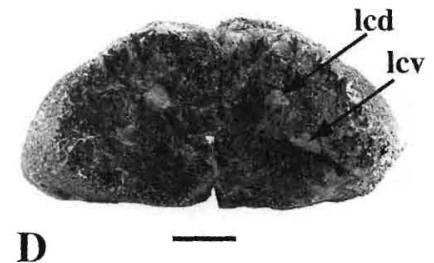

FIGURE 3. Rostrum of Xiphiorhynchus sp., specimen NLU1F-3, upper Eocene, Yazoo Clay Formation, Louisiana, U.S.A. A, dorsal view; B, lateral view; $\mathbf{C}$, ventral view; $\mathbf{D}$, view of anterior (distal) end of specimen; $\mathbf{E}$, enlarged view of alveoli on ventral surface. Abbreviations listed in text. Scale bar equals $10 \mathrm{~mm}$ (A-C), $5 \mathrm{~mm}$ (D), $0.5 \mathrm{~mm}$ (E). 
inner shelf $(0-20 \mathrm{~m}$ in depth) and middle shelf $(20-100 \mathrm{~m}$ in depth).

Locality 1a (specimen NLU1F-1) has a higher diversity of telcosts and is dominated by benthic, eel-shaped fishes living on, or even in, the bottom sediments. The extremely low frequency of the epipelagic and mesopelagic living genus Bregmaceros $(<1 \%)$ and the rarity of pelagic fishes (Mene and the scombrids, represented by one and two otoliths, respectively) at Locality 1a is significant. The otolith assemblage at Locality 1a indicates a tropical to subtropical, rather shallow environment (inner shelf, ca. $20 \mathrm{~m}$ or slightly deeper) with normal salinity and soft bottom sediments consisting of a mixture of clay and calcium carbonate with minor amounts of silt.

The assemblage at Locality $1 \mathrm{~b}$, which is associated with specimens NLU1F-2 and NLU1F-3, is dominated by Bregmaceros (92\% of the total otoliths), which are small pelagic fishes living mainly in the water layers between 0 and $200 \mathrm{~m}$. An otolith assemblage composed predominantly of Bregmaceros, has been shown to be an excellent indicator of middle shelf conditions (20-100 $\mathrm{m}$ in depth) by several studies in the Gulf Coast Eocene (Breard and Stringer, 1995; Stringer and Breard, 1997; Nolf and Stringer, 2003). Conditions at Locality $1 \mathrm{~b}$ remained tropical to subtropical with normal salinity, but depth increased to middle shelf $(20-100 \mathrm{~m})$. All of the paleoecological data based on otoliths from the Yazoo Clay Formation indicates that the environment evolved from an inner shelf (ca. $20 \mathrm{~m}$ ) with an abundant benthic life of both invertebrates and fishes (Locality 1a) to a deeper, more clay-dominated bottom, middle shelf $(20-100 \mathrm{~m})$ environment with less abundant benthic life and more exposed to the pelagic realm (Locality $1 \mathrm{~b}$ ).

Fierstine and Starnes (2005) hypothesized why xiphiorhynchins were found in shallow water deposits even though they are thought to have environmental preferences (temperate to tropical offshore waters greater than $100 \mathrm{~m}$ in depth) similar to their sister taxon, the extant swordfish (Xiphias yladius). Their explanations are pertinent to understanding the presence of xiphiorhynchins in both inner shelf and middle shelf units in the Yazoo Clay. They argued that the rostrum of $X$. cf. $X$. eocaenicus discovered in an inner shelf unit (ca. $20 \mathrm{~m}$ in depth) of the Moodys Branch Formation (middle Eocene), Mississippi, could have been transported into shallow water either as remains of a stranded individual or of an animal that died in shallow water after being impaled.

The holotype of $X$. kimblalocki, was collected in the Shubuta Member of the Yazoo Clay, a deepwater deposit (presumably an outer shelf unit) in Mississippi (Manning, 2003). Because the bones of the holotype do not show much wear, breakage, or chemical etching, we postulate that they were the remains of an individual that died and became buried in deep water. On the other hand, the two rostra of $X$. kimblalocki (specimens NLU1F-1 and NLU1F-2) were found in strata that were deposited at different depths, yet both are nearly identical in morphology and state of preservation (i.e., fairly unworn, distal segments that are missing their distal tips). We cannot rule out that each rostrum was impaled in an animal that died, one at a different depth than the other. However we favor the explanation that each rostrum was the remains of a stranded individual, one carcass remaining in shallow water and the other washing back into deeper water. Both rostra were subject to similar physical wear by currents. Specimen NLU1F-3, a poorly prescrved middle segment identified as Xiphiorhynchus sp., was collected in the same middle shelf horizon as specimen NLU1F-2. Its state of preservation is consistent with long exposure to the elements and could have been transported from a more shallow or deeper area of the shelf.

Acknowledgments-Special appreciation is expressed to the late S. Breard, Jr. (Biostratigraphix, Inc., Houston, Texas, U.S.A.) who donated two of the specimens and to P. Ramsey
(Biology Department, Louisiana Tech University, Ruston, Louisiana, U.S.A.) who provided the third specimen. Thanks to R. Böttcher (SMNS) and S. McLeod (LACM) for allowing examination of specimens in their custody. F. Vernaccia (San Luis Diagnostic Center, San Luis Obispo, California, U.S.A.) provided computer tomography (CT) scans. We appreciate the attention to detail and thoughtful remarks of two anonymous reviewers. A. Fierstine provided support and encouragement throughout the study. The Endowed Professorship in Geology at University of Louisiana at Monroe provided financial support for the project.

\section{LITERATURE CITED}

Agassiz, L. 1833-1844. Recherches sur les Poissons fossiles. Histoire de 1'Ordre des Ganoïdes. Neuchâtel 2:255-257; 5:1-222.

Berggren, W. A., D. V. Kent, C. C. Swisher, III, and M.-P. Aubry. 1995. A revised Cenozoic geochronology and chronostratigraphy; pp. 129-212 in W. A. Berggren, D. V. Kent, M.-P. Aubry, and J. Harenbol (eds.), Geochronology, Time Scales and Global Stratigraphic Correlation. Society of Sedimentary Geology, Special Publication 54.

Bleeker, P. E. 1859. Enumcratio Specierum Piscium hucusque in Archipelago Indico observataum. Verhandelingen der Natuurkundige Vereeniging in Nederlandsch Indië 6:1-276.

Breard, S. Q., and G. L. Stringer. 1995. Paleoenvironment of a diverse marine vertebrate fauna from the Yazoo Clay (Tate Eocene) at Copenhagen, Caldwell Parish, Louisiana. Transactions of the Gulf Coast Association of Geological Societies 45:77-85.

Casier, E. 1966. Faune ichthyologique du London Clay. London, British Museum (Natural History), 2 vols., $496 \mathrm{pp}$.

Dockery, D. T. 1996. Toward a revision of the generalized stratigraphic column of Mississippi. Mississippi Geology 17:1-9.

Fierstine, H. L. 2001. Analysis and new records of bilfish (Teleostei: Perciformes: Istiophoridae) from the Yorktown Formation, carly Pliocene of Eastern North Carolina at Lee Creek Mine; pp. 21-69 in C. F. Ray and D. J. Bohaska (eds.), Geology and Paleontology of the Lee Creck Mine, North Carolina III. Smithsonian Contributions to Paleobiology 90.

Fierstine, H. L., and S. P. Applegate. 1974. Xiphiorhynchus kimblalocki, a new billish from the Eocene of Mississippi with remarks on the systematics of xiphioid fishes. Bulletin of the Southern California Academy of Sciences 73:14-22.

Fierstine, H. I... and J. E. Starnes. 2005. Xiphiorhynchus cf. X. eocaenicus (Woodward, 1901), (Scombroidei: Xiphiidae: Xiphiorhynchinae) from the middle Eocene of Mississippi, the first transatlantic distribution of a species of Xiphiorhynchus. Journal of Vertebrate Paleontology 25:280-287.

Fierstine, H. I., and N. L. Voigt. 1996. Use of rostral characters for identifying adult billfishes (Teleostei: Perciformes: Istiophoridae and Xiphiidae). Copeia 1996:148-161.

Gibbes, R. W. 1847. On the fossil genus Basilosaurus Itarlan (Zeuglodon, Owen) with a notice of specimens from the Eocenc Green Sand of South Carolina. Journal of the Acadeny of Natural Sciences of Philadelphia 1:2-15.

Kilmartin, K. C. 1982. Ostracoda systematics; pp. 111-145 in J. A. Schiebout and W. A. van den Bold (eds.), Paleontological investigations in the vicinity of Montgomery Landing, Red River Waterway, Corps of Engineers, New Orjcans Districh, Report DACW 29-79-0282.

Manning, E. M. 2003. The Eocene-Oligocene transition in marine vertcbrates of the Gulf Coastal Plain; pp. 366-385 in D. R. Prothero, L. C. Ivany, and E. A. Nesbitt (eds.), From Greenhouse to Icehouse, The Marine Eocene-Oligocene Transition. Columbia University Prcss, New York.

Manning, E. M., and B. R. Standhardt. 1986. Late Eocene sharks and rays of Montgomery Landing, Louisiana; pp. 197-209 in J. A. Schiebout and W. A. van den Bold (eds.), Montgomery Landing Site, Marine Focene (Jackson) of Central Louisiana. Symposium Proceedings, Baton Rouge Meeting, Gulf Coast Association of Geological Societies.

Monsch, K. A. 2005. Revision of the Scombroid fishes from the Cenozoic of England. Transactions of the Royal Society of Edinburgh: Earth Sciences 95:445-489. 
Monsch, K. A., H. I. Fierstinc, and R. E. Weems. 2005. Taxonomic revision and stratigraphic provenance of ' $\rightarrow$ Histiophorus rotundus" Woodward 1901 (Teleostei, Perciformes). Journal of Vertebrate Paleontology 25:274-279.

Müller, J. 1844. Über den Bau und die Grenzen der Ganoiden, und Ÿber das natürliche System der Fische. Physikalich-Mathematische Abhandlungen der köninglichen Akademie der Wissenschaften zu Berlin 1845:117-216.

Nelson, J. S. 1994. Fishes of the World, 3rd ed. John Wiley and Sons, Inc. New York, New York, 600 pp.

Nolf, D., and G. L. Stringer, 2003. Late Eocenc (Priabonian) fish otoliths from the Yazoo Clay at Copenhagen, Louisiana. Jouisiana Geological Survey Geological Pamphlet, no. 13:1-23.

Regan, C. T. 1909. On the anatomy and classification of the scombroid fishes. Amnals and Magazine of Natural History 8:66-75.

Stringer, G. L., and S. Q. Breard. 1997. Comparison of otolith-based paleoecology to other fossil groups: an example from the Cane River Formation (Eocene) of Louisiana. Transactions of the Gulf Coast Association of Geological Societics 47:563-570.

Swainson, W. 1839. The Natural History of Fishes, Amphibians, and
Reptiles or Monocardian Animals II. Longman, Orme, Green and Longmans \& John Taylor, London, 448 pp.

van Beneden, P. J. 1871. Recherches sur queloues poissons fossiles de Belgique. Bulletin de l'Academie Royale des Sciences, des Lettres et des Beaux-Arts de Belgique, series 3, 31:493-518.

Weiler, W. 1929. Ergebnisse der Forschungsteisen Prof. E. Stromers in den Wüsten Ägyptens. V. Tertiäre Wirbeltiere. 3. Die Mittel-und oberencinne Fischfauna Agyptens mit besonderer Berücksichtigung der Teleustomi. Abhandlungen der Bayerischen Akademie der Wissenschaften Mathematisch-Naturwissenschaftliche Abteilung. Neu Folge 1:1-57.

Woodward, A. S. 1901. Catalogue of the Fussil Fishes in the British Museum (Natural History). London, British Museum (Natural History). 4, $636 \mathrm{pp}$.

Zullo, V. A., and R. T. Perreault. 1986. Biostratigraphy and paleoecology of Eocene barnacles (Cirripedia) from Montgomery Landing, central Louisiana; pp. 231-238 in J. A. Schiebout and W. A. van den Bold (eds.), Montgomery Landing Site, Marine Eocene (Jackson) of Central Louisiana. Symposium Proceedings, Baton Rouge Meeting, Gulf Coast Association of Geological Societies.

Submitted March 30, 2006; accepted September 4, 2006. 